\title{
Application of Silica Nanoparticles Induces Seed Germination and Growth of Cucumber (Cucumis sativus)
}

\author{
A. H. Alsaeedi', M. M. Elgarawany ${ }^{2}$, H. El-Ramady ${ }^{3}$, T. Alshaal ${ }^{3 *}$, \\ and A. O. A. AL-Otaibi ${ }^{4 *}$ \\ ${ }^{1}$ Department of Environment and Natural Resources, Faculty of Agriculture and Food Science, \\ ${ }^{2}$ Training and Research Station of Agricultural and Veterinary, King Faisal University, Saudi \\ Arabia, ${ }^{3}$ Department of Soil and Water, Faculty of Agriculture, Kafrelsheikh University, Egypt, \\ and ${ }^{4}$ Graduate Student, Ministry of Municipal and Rural Affairs, Saudi Arabia \\ garawany5000@yahoo.com
}

\begin{abstract}
Five rates of nano-silica (NS) suspensions (0, 100, 200, 300 and $\left.400 \mathrm{mg} \mathrm{L}^{-1}\right)$ were used to study their effects on seed germination and growth development of cucumber (Cucumis sativus). The rate of $200 \mathrm{mg} \mathrm{L}^{-1}$ significantly increased final germination $\%$, germination speed, vigor index, and germination index by $28.7,70.3,46.7$ and $68.8 \%$, respectively, compared to untreated seeds. However, it reduced the mean germination time by $31.7 \%$. Similarly, $200 \mathrm{mg} \mathrm{L}^{-1}$ NS had the highest fresh and dry weight of germinant. However, all NS treatments enhanced the seed germination and growth development in comparison to control.
\end{abstract}

Keywords. Nano-silica, Seed germination, Vigor index, Mean germination time, Growth, Cucumber.

\section{Introduction}

Although Si has a pivotal role in humans and is classified as trace necessary element, its essentiality for higher plants is not documented well in recent publications and still under debate. Plant physiologists identify $\mathrm{Si}$ as beneficial element based on fact that plant can complete its life cycle without $\mathrm{Si}$ addition. Design a free-Si growth medium for plant, however, is difficult so it is not sure that if plants are able to successfully complete their life cycle apart from Si supply (Epstein, 1999 and 2009). The role of Si in life cycle of lower forms of life such as corals, diatoms and sponges was known and established in 1960s (Carlisle, 1997). Many publications, recently, documented that some plants particularly ferns and monocots (such as wheat, rice and corn) uptake Si in amounts higher than some macroessential elements and they are able to accumulate $\mathrm{Si}$ in high amounts in their tissues (0.1-15\% of their dry masses according to plant species) (Takahashi et al., 1990; Ma et al., 2001; Ma and Takahashi, 2002; Hodson et al., 2005; Ma et al., 2008), and they named these plants as Si-accumulators. This knowledge could support considering $\mathrm{Si}$ as essential element for plants as in human. Moreover, Si alleviates many of biotic (e.g. diseases, fungi, pathogens and herbivores) and abiotic stresses (e.g. drought, salinity, UV light, lodging and low/ high temperature) in

\footnotetext{
*Corresponding author: Mohammed Mohammed Elgarawany: King Faisal University, Al-Hassa, 31982, Saudi Arabia, E-mail address: garawany5000@yahoo.com; Telephone: (+966) 532381649
} 
plants and helps them to tolerate these unfavourable growth conditions (Farooq et al., 2015).

Occurrence of $\mathrm{Si}$ in soil solution in available form for plants whether indigenously (from weathering silicate-containing rocks) and/ or artificially (from silicate-containing fertilizers) was found to positively affect soil properties and increase availability of phosphorous (Fischer, 1929; Brenchley et al., 2008). This could be due to the role of Si to increase levels of organic phosphoesters when phosphorous is low in soil solution, subsequently enhance uptake and use of phosphorous in plant tissues (Cheong and Chan, 1973). Contrarily, Si declines the toxicity of excess phosphorous in soil through decreasing its availability. So, Si creates a buffer system for phosphorous in soils (Ma et al., 2001). Likewise, Si application via silicate-containing fertilizers reduces the toxic effect of many heavy metals such as cadmium $(\mathrm{Cd})$, arsenic (As), aluminum (Al), zinc ( $\mathrm{Zn})$, iron $(\mathrm{Fe})$ and manganese $(\mathrm{Mn})$ by forming insoluble complexes with them (Liang et al., 2005; da Cunha et al., 2008; Naeem et al., 2014). However, these immobilized metal complexes act as a good source for plant nutrition under metal deficiency periods by remobilizing these complexes and make them available for plants as assessed for iron in cucumber and soybean (Gonzalo et al., 2013; Pavlovic et al., 2013; Bityutskii et al., 2014). Plants can uptake Si either through active or passive transportation depending on plant species. Many studies reported that specific monocots such as wheat, rice, maize and barely uptake Si mainly by active transport system (Takahashi et al., 1990; Mitani et al., 2009; Ma et al., 2011) and accumulate Si in their tissues in high amounts, therefore they decrease the free $\mathrm{Si}$ concentration in soil. These Si-accumulators accumulate $\mathrm{Si}$ in their above ground parts as phytoliths ( $\mathrm{Ma}$ and
Yamaji, 2006). Although Si represents 28\% from the earth's crust, adding Si to soil and plants as fertilizer is considerably required to increase its available concentration in soil solution, and thus guarantees adequate $\mathrm{Si}$ supply for plants. Manufacturing essential and/ or beneficial elements in nanoscale and introduce them to plants as biofertilizers has gained the attention of researchers during last decade. Their unique characteristics provide them advantage for uptake by plants over traditional forms of fertilizers due to the tiny size that give faster access throughout the channels and pores located in cell wall.

Silicon ( $\mathrm{Si}$ ) is the second most abundant element in the soil. Silicon plays an important role in plant growth in protecting plants against changes in environmental conditions. However, silicon is not considered an essential element. Recently, numerous studies have shown that treatment with silicon significantly alleviated salt, drought, chilling and freezing stress in plants (Almutairi, 2016). Additionally silicon acts as growth stimulant, e.g for larger leaves (McNaughton, 1985) with bigger biomass (Epstein, 1999) and increases the yield of crop plants like sugar cane or rice (Savant et al., 1999; Korndorfer et al. 2001). Silicon promotes several physiological processes in plants (Korndorfer et al. 2001). The Si treatments were considered beneficial to plant growth and production (Liang et al., 2007; Ma and Yamaji, 2008).

Nanosilica is an important metal oxide that covers all major fields of science and technology including industrial, electronics and biomedical applications (Paulkumar et al., 2011; Dinda et al., 2012; Cheng et al., 2008). Agricultural application of nanoparticles is currently an interesting area of interest (Karunakaran et al., 2013). The introduction of nanoparticles into plants might have significant impact and thus, it can be used for agricultural applications for better growth and 
yield. Generally, several studies are made on toxicity of nanoparticles on seed germination which are based on germination rates obtained with response to nanoparticles (Josko, and Oleszczuk, 2013; Lin and Xing, 2007). An earlier study shows that the addition of nanosilica in soil enhances growth of maize (Zea mays L.) (Yuvakkumar et. al, 2011). Even though different sources of silica are used as silicon fertilisers, ecotoxicological properties and the risks of silicon fertilizers in terms of soil microbial health and soil nutrient values are found to be scanty to the best of our knowledge. It is well known that plant growth promoting rhizobacteria (PGPR) plays a key role in recycling and maintenance of soil health which improves plant growth(Supanjani et al.,2006; Khakipour et al., 2008; OrtízCastro et al., 2008; Gholam et al., 2009). Nanosilica promoted seed germination percentage $(100 \%)$ in maize than conventional Si sources (Karunakaran et al., 2013). They added that almost all the seeds are germinated in the pot containing nanosilica, giving $100 \%$ seed germination followed by control (95\%), micron silica (97\%), tetraethyl orthosilicate (TEOS, 83\%), silicic acid (73\%) and sodium silicate $(5 \%)$.

Silicon nanoparticles (N-Si) have been implicated in crop improvements. Many reports indicate that appropriate concentrations of N-Si increase seed germination (Karunakaran et al., 2013), plant growth (Yuvakkumar et al., 2011) and plant resistance to hydroponic conditions (Suriyaprabha et al., 2012). Recently, the role of N-Si in the mitigation of salt stress received worldwide attention because of reports about the ability of $\mathrm{N}-\mathrm{Si}$ to counteract the negative effects of salt on plant growth rates. Haghighi et al. (2012) found that N-Si reduced the negative effects of salinity on tomatoes during germination, in which treatment with $1 \mathrm{mM} \mathrm{N}-\mathrm{Si}$ increased the germination rate, root length and dry weight of tomato plants in $25 \mathrm{mM} \mathrm{NaCl}$ conditions. By contrast, $2 \mathrm{mM} \mathrm{N}-\mathrm{Si}$ inhibited the germination of plants grown in $50 \mathrm{mM} \mathrm{NaCl}$ conditions. Sabaghnia and Janmohammadi (2014) found that the application of $1 \mathrm{mM}$ nano-silicon dioxide (N-SiO2 ) provided considerable alleviation of the adverse effects of salt stress on the germination percentage of lentil seeds. The length of the roots and shoots, seedling weight, mean germination time, seedling vigour index and seed reserve mobilization were also positively affected. In a study by Abdul Qados and Moftah (2015), the application of $\mathrm{Si}$ and $\mathrm{N}-\mathrm{SiO} 2$ significantly increased the germination of Vicia faba L. seeds under 107 salinity stress. Among the treatments, the $2 \mathrm{mM} \mathrm{Si}$ and the $\mathrm{NSiO} 2$ treatments improved germination characteristics. Relative water content, plant height, and fresh and dry weights also increased in treatments with $\mathrm{Si}$ or $\mathrm{N}-\mathrm{Si}$. In basil (Ocimum basilicum), leaf dry and fresh weights, chlorophyll content and proline content increased after treatment with $\mathrm{NSi}$ under salinity stress (Kalteh et al., 2014). The germination percentage and germination rate of tomato seeds and the root length and fresh weight of tomato seedlings were increased after exposure to $\mathrm{N}-\mathrm{Si}$ under $\mathrm{NaCl}$ stress (Almutairi, 2016). The current research aimed to investigate the effect of silica nanoparticles on seed germination of cucumber and its development after germination.

\section{Materials and Methods}

\subsection{Seed Germination of Cucumber}

Random completely randomized design with three replicates and four different concentrations of nano-silica suspensions (ns0, ns100, ns200, ns300 and ns 40 as 0, 100, 200, 300 and $400 \mathrm{mg} \mathrm{L}^{-1}$, respectively) were used to compare their effects on seed germination of cucumber (Cucumis sativus) and distilled water was applied as a control. Nano-silica 
suspensions were prepared using synthesised hydrophilic nano-silica (Aerosil 300 produced by Evonik Industries, Germany) which has a specific surface area of 270-330 $\mathrm{m}^{2} \mathrm{~g}^{-1}, \mathrm{pH}$ (3.7-4.5), and mean diameter $(10 \mathrm{~nm})$. Fifteen seeds of cucumber per each replicate were washed thoroughly with distilled water then immersed in hypochlorite solution $10 \%$ for 5 minutes for surface cleaning before experiment. Then seeds were equally distributed on doubled filter paper in a $15 \mathrm{~cm}$ diameter sterilized petri dishes to allow seeds to germinate. Seeds of each treatment were first soaked in nano-silica suspension (with same concentration as applied in its nano-silica treatment) for 4 hours before transplanting. Each replicate received $15 \mathrm{~mL}$ of its tested nano-silica treatment. All petri dishes were sealed well to prevent drying and maintained moist and wet across the experiment period of 10 days. All petri dishes were placed in dark place with room temperature of $23 \pm 2 \mathrm{C}^{\circ}$. Daily count of germinant was done from the onset of germination up to 10 days thereafter with minimum length of $2 \mathrm{~mm}$ emergent radicle. At the end of experiment, fresh and dry masses were taken for each replicate. Germination indicators were calculated as follow:

a) Final germination percentage (FGP) was computed as percentage (Ranal and Santana, 2006) using the formula:

$$
\mathrm{FGP}=\left[\frac{\mathrm{TNG}}{\mathrm{TNP}}\right] * 100
$$

Where, FGP = final germination percentage; $\mathrm{TNG}=$ total number of germinated seeds; and $\mathrm{TNP}=$ total number of planted seeds.

b) Mean germination time (MGT) was calculated by formula cited by Mauromicale and Licandro (2002) given below:

$$
\mathrm{MGT}=\sum\left(\frac{n i * t i}{n i}\right)
$$

Where, $\mathrm{MGT}=$ mean germination time; $\mathrm{ni}=$ the number of germinated seeds on day ti; $\mathrm{ti}=$ the number of days during the germination period (between 0 and 10 days);

The mean germination time was used to evaluate seedling emergence.

c) Germination speed (GS) was computed as described by (Czabator, 1962) using the formula presented below:

$$
\mathrm{GS}=\sum\left(\frac{n i}{t i}\right)
$$

Where, GS = germination speed.

d) Vigor index (VI) was calculated using the formula of Kharb et al. (1994), as follows:

$$
\mathrm{VI}=\left[\frac{\mathrm{SDM}(\mathrm{g}) * \mathrm{GP}}{100}\right]
$$

Where, $\mathrm{VI}=$ vigor index; SDM = seedling dry mass (g); GP = germination percentage.

c) Coefficient of velocity of germination (CVG) was calculated after Jones and Handreck (1967) by the following formula:

$$
\mathrm{CVG}=\frac{\sum \mathrm{ni}}{\sum \mathrm{ni} * \mathrm{ti}} * 100
$$

Where, $\mathrm{CVG}=$ coefficient of velocity of germination.

f) Germination index (GI) was computed as in the Association of Official Seed Analysts (AOSA, 1983) by following formula:

$$
\mathrm{GI}=\frac{\mathrm{n}}{\mathrm{d}}
$$

Where, GI = germination index; $\mathrm{n}=$ number of seedlings emerging on day ' $d$ '; $d=$ day after planting.

\subsection{Growth of Cucumber Seedlings}

The aim of this experiment was to study the development of cucumber seedlings within the first three weeks after germination. Therefore, plastic pot $(5 \mathrm{~cm} \times 5 \mathrm{~cm} \times 8 \mathrm{~cm})$ 
was filled with $115 \mathrm{~g}$ of nursery mixture comprising of sand and peat moss at 1:1 ratio with saturation percentage of $80 \%$. Seeds of cucumber were washed thoroughly with distilled water before soaking in nano-silica suspension for four hours according to their treatment before sowing. One seed per each pot was covered by $1 \mathrm{~cm}$ layer of growth mixture (sand and peat moss), and irrigated by distilled water during experiment to keep it wet at almost $65 \%$ from its saturation percentage. The pots were placed in greenhouse with average daily temperature of $24 \pm 2 \mathrm{C}^{\circ}$. Nano-silica treatments were 0,100 , 200, 300, and $400 \mathrm{mg} \mathrm{L}^{-1}$. Each pot received $100 \mathrm{~mL}$ of its treatment of nano-silica suspension. The nano-silica dose was divided on weekly basis to $50 \%(50 \mathrm{~mL})$ before planting and second $50 \%(50 \mathrm{~mL})$ one week after transplanting. All measurements of shoot length, root length, and dry shoot and root masses were taken after three weeks.

\subsection{Statistical Analysis}

Data analysis was performed using Microsoft Excel 2010 (mean values and standard deviation) from two individual experiments, and the statistical analysis was conducted using the XLSTAT software package. When a significant difference was observed between treatments, multiple comparisons were made by the Fisher's test. Significant differences were accepted at the level $p<0.05$.

\section{Results and Discussion}

\subsection{Seed Germination Indices}

\subsubsection{Analysis of variance of The Growth characteristics, yield and yield components}

Analysis of variance of the cucumber seed growth characteristics under the effects of five nano-silica levels are presented in Table (1). The results revealed significant differences due to applied nano-silica with regard final growth percentage (FGP, $\mathrm{p}<0.01$ ), growth speed (GS, p < 0.001), coefficient of velocity of germination (CVG, $\mathrm{p}<0.001$ ), mean germination time (MGT, $\mathrm{P}<0.01$ ) vigor index $(\mathrm{VI}, \mathrm{p}<0.05)$ and germination index (GI, $\mathrm{p}<$ $0.001)$. These findings are consistent with the results found Sabaghnia and Janmohammadi (2014) found that the application of $1 \mathrm{mM}$ nano-silicon dioxide $\left(\mathrm{N}-\mathrm{SiO}_{2}\right)$ has a positive effect on the length of the roots and shoots, seedling weight, mean germination time, seedling vigour index of the lentil seeds.

\subsubsection{Final germination percentage ( $F G P$ )}

Data presented in Table 2 showed the calculated values of final germination percentage (FGP, \%) of cucumber's seeds after treating with different nano-silica concentrations. All nano-silica treatments, significantly, recorded higher FGP compare to untreated seeds with nano-silica (control). However, treatments of 200 and $300 \mathrm{mg} \mathrm{L}^{-1}$ nano-silica achieved 100\% FGP after 10 days, while control seeds germinated with $77.7 \%$. FGP of seeds received 100 and $400 \mathrm{mg} \mathrm{L}^{-1}$ nano-silica was 95.3 and $93.3 \%$, respectively. The rate of $200 \mathrm{mg} \mathrm{L}^{-1}$ increased final germination $\%$ by $28.7 \%$ compared to untreated seeds. Crop productivity depends on many genetic and environmental factors, seed germination is considered the primary step that ensures and determines whether the further agricultural practices and final production will achieve the desire yield or not (Bhattacharjee 2008; Al-Mudaris 1998). Our recent results are in agreement with those reported by Lu et al. (2015) who mentioned that FGP of tomato increased by $70.3 \%$ after application of nanosilica suspension with $5 \mathrm{~g} \mathrm{~L}^{-1}$ against control seeds. Likewise, an increase of 2-11 \% was found in seed germination of maize after treating with nano-silica (Yuvakkumar et al., 2011). Germination of rice seeds was induced also by using nano-silica as reported by Nair et al. (2011). 


\subsubsection{Germination speed(GS)}

Germination speed (GS, \%/day) describes in details the dynamics of germination, where it shows how many seeds germinate per day. The values of GS are depicted in Table 2. Control seeds of cucumber germinated daily by $21.2 \%$, while treated seeds with nano-silica had a daily germination percentage of $30.1 \%$ as the lowest recorded value in case of treatment of $100 \mathrm{mg} \mathrm{L}^{-1}$ nano-silica. However, treating seeds with $200 \mathrm{mg} \mathrm{L}^{-1}$ nano-silica germinated by the highest GS (36.1\% as comparison with control treatment). These results prove that nano-silica significantly and positively induces seed germination of cucumber in comparison with control seeds. Our data is confirmed by those findings of Khalaki et al. (2016) who cited that GS of Thymus kotschyanus enhanced by application of nano-silica under in vitro circumstances.

\subsubsection{Coefficient of velocity of germination (CVG)}

Coefficient of velocity of germination $(\mathrm{CVG})$ is an indicator for germination rapidity. Its value depends on how many seeds are germinated, as number of germinated seeds increases as CVG increases and germination time decrease. The highest possible value of CVG, theoretically, is 100 (Al-Mudaris, 1998). Using of nano-silica in the current investigation resulted in significant differences in CVG values between control seeds of cucumber and treated seeds with nano-silica as shown in Table 2. Untreated seeds had a CVG of 24.9, but treated seeds with different nanosilica concentrations, on the other hand, had higher values. The highest recorded CVG was $35.2(41.40 \%$ as comparison with control treatment) when nano-silica was applied with concentration of $200 \mathrm{mg} \mathrm{L}^{-1}$. However, the higher concentrations of nano-silica e.g. 300 and $400 \mathrm{mg} \mathrm{L}^{-1}$, also increased the CVG than control recording 31.1 and 30.7 , respectively.
Higher values of $\mathrm{CVG}$ are indicator for the good effect of used treatments as the ideal value of CVG is 100 .

\subsubsection{Mean germination time (MGT)}

The time that a seed needs to start and end its germination is called mean germination time (MGT). MGT is measured by unit of day or simply how many days seeds need to complete their germination. Shorter time of germination, of course, is better than longer time, therefore any treatment will diminish the MGT will be important and its effect will reflect on vigorousness of seedlings and finally the productivity. Figure 1 presents data of MGT of cucumber seeds during the germination experiment. Application of nano0silica found to have significant effect on MGT of seeds where significant differences were calculated. When control seeds required 4.1 day for complete germination, treated seeds with $200 \mathrm{mg} \mathrm{L}^{-1}$ nano-silica needed only 2.8 days. Furthermore, other nano-silica treatments such as 100, 300 and $400 \mathrm{mg} \mathrm{L}^{-1}$ found to reduce the MGT in comparison to control seeds. Similarly, Suriyaprabha et al. (2012) found that nano-silica positively decreased the MGT of maize seeds, but $\mathrm{Na}_{2} \mathrm{SiO}_{3}$ increased the MGT while micro-SiO and $\mathrm{H}_{4} \mathrm{SiO}_{4}$ had no effect on MGT of Maize seeds during the germination process. Also, these results confirmed by experiment done by Azimi et al. (2014) who reported that adding nano-silica by $40 \mathrm{mg} \mathrm{L}^{-1}$ diminished the MGT of tall wheatgrass seeds to the shortest germination period that has been recorded.

\subsubsection{Vigor index (VI)}

Results of vigor index (VI) of cucumber seeds treated with and without nano-silica are denoted in Fig. 1. As the higher the vigor index, as the stronger the seedling. Clearly, germinating cucumber seeds in presence of nano-silica resulted in vigor seedlings compared to control. All treatments of nano- 
silica had higher VI than control seeds. The highest measured VI was found when seeds received $200 \mathrm{mg} \mathrm{L}^{-1}$ nano-silica. However, VI of 2 and 2.1 was found at 100 and $300 \mathrm{mg} \mathrm{L}^{-1}$ nano-silica compare to VI of 1.5 for control seeds.VI is an important characteristic of seed germination, this importance comes from its ability to determine and specify if seedlings will be able to keep growing well after germination or not. Our results are supported by other results cited by Azimi et al. (2014) who said that adding nano-silica by $40 \mathrm{mg} \mathrm{L}^{-1}$ increased VI of tall wheatgrass seeds by $120 \%$ against control seeds. In the same way, $\mathrm{Lu}$ et al. (2015) found that treating tomato seeds with $7 \mathrm{~g} \mathrm{~L}^{-1}$ of nano-silica increased its VI.

\subsubsection{Germination index (GI)}

Germination index (GI) is a function of germination percentage and rate of germination. High values of GI give information that most seeds germinate early in short period of time, while low values mean most of seeds germinate late close to $10^{\text {th }}$ day of germination (Al-Mudaris, 1998). Absence of nano-silica from germination medium as in control reduced GI values recording 3.2, while using nano-silica with concentration of $200 \mathrm{mg}$ $\mathrm{L}^{-1}$ in germination medium increased GI to be 5.4 as the highest measured value among all treatments (Fig. 1). However, all nano-silica treatments had higher and significant GI than control. GI for treatments of 100, 300 and 400 $\mathrm{mg} \mathrm{L}^{-1}$ nano-silica was $4.5,4.9$ and 4.5 , respectively.

\subsubsection{Fresh and dry weight of germinant}

Data of fresh (FW) and dry (DW) weight of germinant as well as its relative water content (RWC) are presented in Table 3. As a consequence for inducing germination percentage and producing vigor germinant by using nano-silica, all vegetative parameters were also enhanced significantly by adding nano-silica for growth medium. Almost, all treated seeds with nano-silica had higher values of FW, DW and RWC than untreated seeds. From the presented data, application of nano-silica by $200 \mathrm{mg} \mathrm{L}^{-1}$ achieved the highest values of FW, DW and RWC recording 0.317 and $0.022 \mathrm{~g}$ germinant $^{-1}$ and $93.0 \%$, respectively. However, the difference between other nano-silica treatments (e. g. 100, 300 and $400 \mathrm{mg} \mathrm{L}-1)$ were insignificant.

\subsection{Growth of Cucumber Seedlings}

\subsubsection{Root and shoot length}

Seedlings of cucumber were grown on mixture (50:50) sand: peat moss for three weeks under greenhouse conditions to monitor the dynamic and development of seedlings after treating with different concentrations of nano-silica. Application of nano-silica to growth medium enhanced gradually the length of root and shoot systems of cucumber seedlings up to $200 \mathrm{mg} \mathrm{L}^{-1}$ nano-silica, then reduced linearly but still higher than control seedlings (Table 3 ). The longest root and shoot systems were found when nano-silica was used by rate of $200 \mathrm{mg} \mathrm{L}^{-1}$ recording 6.51 and 5.10 $\mathrm{cm}$, respectively. When control seedlings had $3.82 \mathrm{~cm}$ shoot length, the shortest shoot found under nano-silica treatments was $4.38 \mathrm{~cm}$ at treatment of $400 \mathrm{mg} \mathrm{L}^{-1}$ (Table 4).

\subsubsection{Dry weight of root and shoot}

Dry weight of cucumber seedlings after three weeks was improved by using nanosilica, as treated seedlings with nano-silica possessed higher root dry weight compared to control seedlings (Table 4). Significantly, root dry weight increased when $100 \mathrm{mg} \mathrm{L}^{-1}$ nanosilica was applied to cucumber seedlings recording the highest dry weight $(0.143 \mathrm{~g}$ plant $^{-1}$ ) of root system among all other treatments including the control (Table 4). Increasing concentration of nano-silica above $100 \mathrm{mg} \mathrm{L}^{-1}$ gradually decreased dry weight of root system but still higher than untreated seedlings with nano-silica. Same tendency was 
found for shoot dry weight except that the highest dry weight of shoot was $0.120 \mathrm{~g} \mathrm{plant}^{-1}$ at treatment of $200 \mathrm{mg} \mathrm{L}^{-1}$, then values decreased with increasing nano-silica doses. The lowest shoot dry weight was $0.077 \mathrm{~g}$ plant $^{-1}$ at control treatment (Table 3). Similar results were documented by other authors such as Siddiqui and Al-Whaibi (2014) who cited that both fresh and dry weights of tomato seedlings induced by using nano-silica. In addition, Suriyaprabha et al. (2012) introduced the same trend for maize plants.

\section{Conclusion}

Recently, nanoparticles were intensively used in agricultural sector because their welldocumented benefits. The crop productivity primarily relies on germination, as success germination ensures suitable number of plants per cultivation area. In addition, the strong seedling guarantees well growing even under biotic and abiotic stresses. In the current research, the importance of nano-silica for seed germination of cucumber seeds was illustrated. However, all treated seeds with nano-silica had better and higher values for all germination parameters and indices. Among nano-silica treatments i.e., 100, 200, 300 and $400 \mathrm{mg} \mathrm{L}^{-1}$, treatment of $200 \mathrm{mg} \mathrm{L}^{-1}$ showed the best effect on all germination and growth characteristics. The highest final germination percentage, germination speed, coefficient of velocity of germination, vigor index, germination index and shortest mean germination time were found when nano-silica was applied with rate of $200 \mathrm{mg} \mathrm{L}^{-1}$. Likewise, the vegetative parameters such as fresh and dry weights shoot and root length and relative water content were also higher under treatment of $200 \mathrm{mg} \mathrm{L}^{-1}$. From results mentioned above it could be concluded that application of 200 $\mathrm{mg} \mathrm{L}^{-1}$ nano-silica is important for germination and growing of cucumber in order to maximize its productivity. This good and desire effect of nano-silica maybe attributed to its small size which allows it to easily cross the cell wall and alert many physiochemical processes which accelerate the germination and growth.

Table 1. Mean of square for plant length, no. of fruits/plant, total fruits weight/plant, marketable fruits weight /plant, ratio of marketable fruit weight/ total fruits weight and fruits firmness of cucumber as affected by different irrigation treatments factors.

\begin{tabular}{|c|c|c|c|c|c|c|c|}
\hline \multirow{2}{*}{$\begin{array}{c}\text { Source } \\
\text { of } \\
\text { variation }\end{array}$} & \multirow{2}{*}{$\begin{array}{c}\text { Degree } \\
\text { of } \\
\text { freedom }\end{array}$} & \multicolumn{5}{|c|}{$\begin{array}{c}\text { Means Squares } \\
\text { Growth and Yield characteristics }\end{array}$} & \multirow[b]{2}{*}{ GI } \\
\hline & & FGP & GS & $\mathrm{CVG}$ & MGT & VI & \\
\hline Rep. & 2 & 84.067 & 3.219 & 4.012 & 0.1082 & 0.0393 & 0.073 \\
\hline $\mathrm{T}$ & 4 & $253.73^{* *}$ & $91.234^{* * *}$ & $40.638^{* * *}$ & $0.6021^{* *}$ & $0.2244^{*}$ & $2.059^{* * *}$ \\
\hline Error & 8 & 32.73 & 2.724 & 3.398 & 0.073 & 0.0385 & 0.0619 \\
\hline
\end{tabular}

$*, * *, * * *$ : significant at $\mathrm{p}<0.05, \mathrm{p}<0.01$ and $\mathrm{p}<0.001$ levels of probability respectively

Notice: experimental unit is 10 seeds of cucumber (Rep.= replications and $\mathrm{T}=$ treatments).

Table 2. Nano-silica doses enhances seed germination parameters of cucumber.

\begin{tabular}{cccc}
\hline Nano-silica doses $\left(\mathbf{m g ~ L}^{-1}\right)$ & FGP $^{*}$ & $\mathbf{G S}^{* *}$ & $\mathbf{C V G}^{* * *}$ \\
\hline ns 0 & $77.7 \mathrm{~b}$ & $21.2 \mathrm{c}$ & $24.9 \mathrm{c}$ \\
ns 100 & $95.3 \mathrm{a}$ & $30.1 \mathrm{~b}$ & $29.6 \mathrm{~b}$ \\
ns 200 & $100.0 \mathrm{a}$ & $36.1 \mathrm{a}$ & $35.2 \mathrm{a}$ \\
ns 300 & $100.0 \mathrm{a}$ & $32.5 \mathrm{~b}$ & $31.1 \mathrm{~b}$ \\
ns 400 & $93.3 \mathrm{a}$ & $30.2 \mathrm{~b}$ & $30.7 \mathrm{~b}$ \\
\hline
\end{tabular}

${ }^{*}$ Final germination percentage $(\%) ;{ }^{* *}$ germination speed $(\% /$ day $) ;{ }^{* * *}$ Coefficient of velocity of germination. Different letters in same column show significant differences among each group of treatments according to Fisher's test at $p<0.05$. 


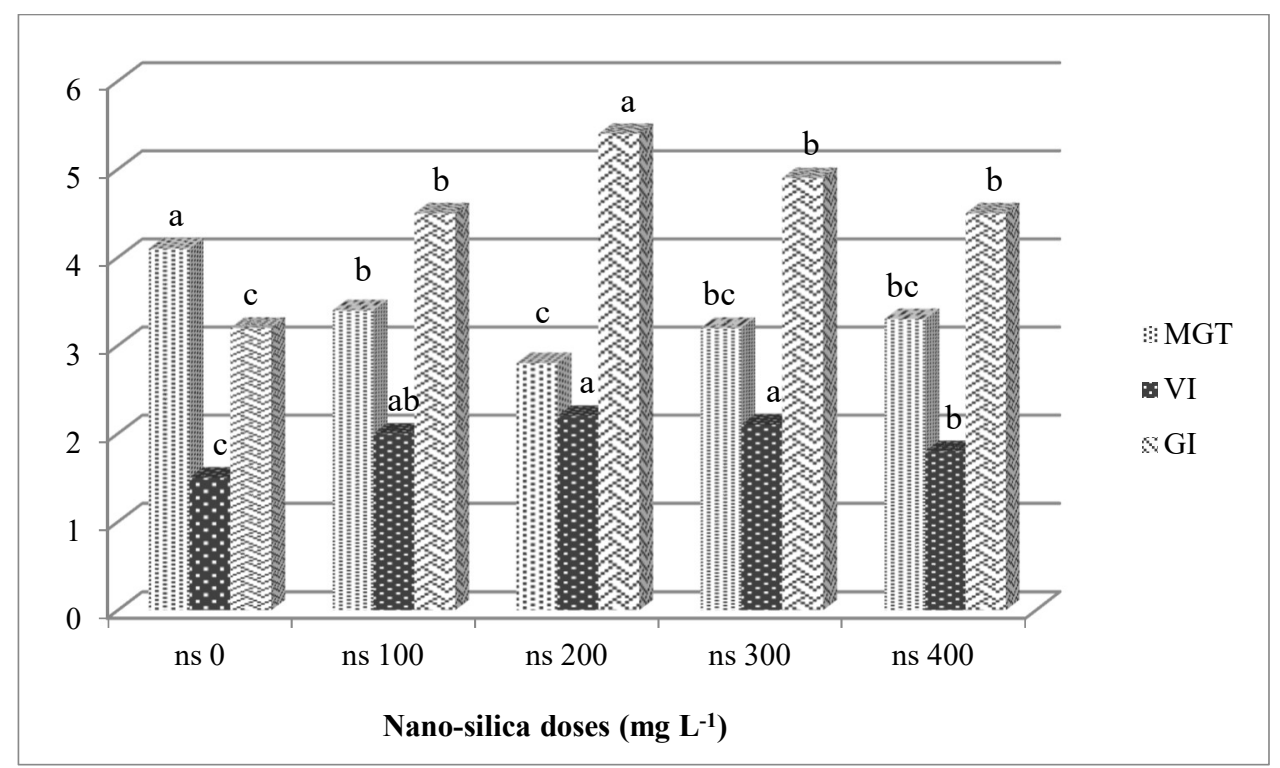

Fig. 1. Application of nano-silica during seed germination of cucumber positively affects mean germination time (MGT), vigor index (VI) and germination index (GI). Different letters over column with same shading degree show significant differences among each group of treatments according to Fisher's test at $p<0.05$.

Table 3. Treating cucumber seeds with nano-silica improves some vegetative indices.

\begin{tabular}{cccc}
\hline Nano-silica doses $\left(\mathbf{m g ~ L}^{-\mathbf{1}}\right)$ & $\mathbf{F W}^{*}$ & $\mathbf{D W}^{* *}$ & RWC $^{* * * *}$ \\
\hline ns 0 & $0.231 \mathrm{~b}$ & $0.019 \mathrm{~b}$ & 91.6 \\
ns 100 & $0.233 \mathrm{~b}$ & $0.021 \mathrm{ab}$ & 90.9 \\
ns 200 & $0.317 \mathrm{a}$ & $0.022 \mathrm{a}$ & 93.0 \\
ns 300 & $0.231 \mathrm{~b}$ & $0.021 \mathrm{ab}$ & 90.9 \\
ns 400 & $0.233 \mathrm{~b}$ & $0.020 \mathrm{ab}$ & 91.4 \\
\hline
\end{tabular}

* Fresh weight (g germinant-1);** dry weight (g germinant-1);*** relative water content (\%). Different letters in same column show significant differences among each group of treatments according to Fisher's test at $\mathrm{p}<0.05$.

Table 4. Vegetative parameters of cucumber seedlings induced by nano-silica suspensions.

\begin{tabular}{|c|c|c|c|c|}
\hline \multirow[t]{2}{*}{ Nanosilica doses $\left(\mathrm{mg} \mathrm{L}^{-1}\right)$} & \multicolumn{2}{|c|}{ Length, cm } & \multicolumn{2}{|c|}{ Dry weight, $g$ plant ${ }^{-1}$} \\
\hline & Root & Shoot & Root & Shoot \\
\hline ns 0 & $5.76 \mathrm{bc}$ & $3.82 \mathrm{c}$ & $0.049 \mathrm{~d}$ & $0.077 \mathrm{c}$ \\
\hline ns 100 & $5.92 \mathrm{abc}$ & $5.01 \mathrm{a}$ & $0.143 \mathrm{a}$ & $0.114 \mathrm{ab}$ \\
\hline ns 200 & $6.51 \mathrm{a}$ & $5.10 \mathrm{a}$ & $0.110 \mathrm{~b}$ & $0.120 \mathrm{a}$ \\
\hline ns 300 & $5.21 \mathrm{c}$ & $4.54 \mathrm{~b}$ & $0.082 \mathrm{c}$ & $0.108 \mathrm{ab}$ \\
\hline ns 400 & $6.06 \mathrm{ab}$ & $4.38 \mathrm{~b}$ & $0.059 \mathrm{~cd}$ & $0.101 \mathrm{~b}$ \\
\hline
\end{tabular}

Different letters in same column show significant differences among each group of treatments according to Fisher's test at $p<$ 0.05 .

\section{References}

Abdul Qados, A.M.S. and Moftah, A.E. (2015) Influence of silicon and nano-silicon on germination growth and yield of faba bean (Vicia faba L.) under salt stress conditions. Am J Soc Hortic Sci., 5(6): 509-524

Al-Mudaris, M. A. (1998) Notes on Various Parameters Recording the Speed of Seed Germination. Der Tropenlandwirt, Beiträge zur tropischen Landwirtschaft und Veterinärmedizin, 99. Jahrgang, Oktober 98, S. 141 154.

Almutairi, Z. M. (2016) Effect of nano-silicon application on the expression of salt tolerance genes in germinating tomato (Solanum lycopersicum L.) seedlings under salt stress. POJ, 9(1):106-114.

AOSA (1983) Handbook of seed science and technology. Published by Food Products Press. 
Azimi, R., Borzelabad, M. J., Feizi, H. and Azimi, A. (2014) Interaction of $\mathrm{SiO} 2$ nanoparticles with seed prechilling on germination and early seedling growth of tall wheatgrass (Agropyron elongatum L.). Polish J Chem Technol, 16(3): 25-29.

Bhattacharjee, S. (2008) Triadimefon pretreatment protects newly assembled membrane system and causes upregulation of stress proteins in salinity stressed Amaranthus lividus L. during early germination. J Environ Biol, 29: 805-810.

Bityutskii, N., Pavlovic, J., Yakkonen, K., Maksimovi, V. and Nikolic, M. (2014). Contrasting effect of silicon on iron, zinc and manganese status and accumulation of metal mobilizing compounds in micronutrient- deficient cucumber. Plant Physiol. Biochem., 74, 205-211.

Brenchley, W. E., Maskell, E. J. and Katherine, W. (2008). The inter-relation between silicon and other elements in plant nutrition. Ann. Appl. Biol., 14, 45-82. doi:10.1111/j.1744-7348.1927.tb07005.x

Carlisle, E. M. (1997). "Silicon," in: Handbook of Nutritionally Essential Minerals, eds B. L. O'Delland R. A. Sunde (New York, NY: Marcel Dekker), 603-618.

Cheng, L., Zheng, L., Li, G., Yao, Z., Yin, Q. and Jiang, K. (2008) Manufacture of epoxy-silica nanoparticle composites and characterisation of their dielectric behavior. Int. J. Nanoparticles, 1: 3-13.

Cheong, Y. W. Y. and Chan, P. Y. (1973). Incorporation of P32 in phosphate esters of the sugarcane plant and the effect of $\mathrm{Si}$ and $\mathrm{Al}$ on the distribution of these esters. Plant Soil, 38: 113-123.

Czabator, F. J. (1962) Germination value: an index combining speed and completeness of pine seed germination. Forest Sci., 8: 386-396.

da Cunha, K. P. V., do Nascimento, C. W. A. and da Silva, A. J. (2008). Silicon alleviates the toxicity of cadmium and zinc for maize (Zea mays L.) grown on a contaminated soil. J. Plant Nutr. Soil Sci., 171, 849-853.

Dinda, A. K., Prashant, C. K., Naqvi, S., Unnithan, J., Samim, M. and Maitra, A. (2012) Curcumin loaded organically modified silica (ORMOSIL) nanoparticle; a novel agent for cancer therapy. Int. J. Nanotechnol, 2012: 862-871.

Epstein, E. (2009) Silicon: its manifold roles in plants. Ann. Appl. Biol., 155: 155-160.

Epstein, E. (1999) Silicon. Annual Review of Plant Physiology and Plant Molecular Biology, 50: 641-664.

Farooq M., Hussain M., Wahid A. and Siddique, K. H. M. (2015) Drought stress in plants: An overview, in: Plant Responses to Drought Stress, 1-33. Springer, Berlin, Heidelberg.
Fischer, R. A. (1929) A preliminary note on the effect of sodium silicate in increasing the yield of barley. J. Agric. Sci, 19, 132-139.

Gholami, A., Shahsavani, S. and Nezarat, S. (2009) The effect of plant growth promoting rhizobacteria (PGPR) on germination, seedling growth and yield of maize. Int. J. Biol. Life Sci., 1:35-40.

Gonzalo, M. J., Lucena, J. J. and Hernández-Apaolaza, L. (2013) Effect of silicon addition on soybean (Glycine max) and cucumber (Cucumis sativus) plants grown under iron deficiency. Plant Physiol. Biochem., 70: 455-461.

Haghighi, M., Afifipour, Z. and Mozafarian, M. (2012) The effect of N_Si on tomato seed germination under salinity levels. J. Biol. Environ. Sci., 6(16): 87-90.

Hodson, M. J., White, P. J., Mead, A. and Broadley, M. R. (2005) Phylogenetic variation in the silicon composition of plants. Annal. Bot., 96:1027-1046.

Jones, L. H. P. and Handreck, K. A. (1967) Silica in soils, plants, and animals p. 107-149. In A.G. Norman (ed.) Advances in Agronomy. Vol. 19. Academic Press, New.

Josko, I. and Oleszczuk, P. (2013) Influence of soil type and environmental conditions on $\mathrm{ZnO}, \mathrm{TiO} 2$ and $\mathrm{Ni}$ nanoparticles phytotoxicity. Chemosphere, 92: 91-99.

Kalteh, M., Alipour, Z., T., Ashraf, S., Aliabadi, M., M. and Nosratabadi, A., F. (2014) Effect of silica nanoparticles on basil (Ocimum basilicum) under salinity stress. J Chem Health Risk, 4(3): 49-55.

Karunakaran, G., Suriyaprabha, R., Manivasakan, P., Yuvakkumar, R., Rajendran, V., Prabu, P. and Kannan, N. (2013) Effect of nanosilica and silicon sources on plant growth promoting rhizobacteria, soil nutrients and maize seed germination. IET Nanobiotechnol, 7(3): 70-77.

Khakipour, N., Khavazi, K., Mojallali, H., Pazira, E. and Asadirahmani, H. (2008) Production of auxin hormone by fluorescent Pseudomonads. American-Eurasian $J$. Agric. Environ. Sci., 4: 687-692.

Khalaki, M. A., Ghorbani, A. and Moameri, M. (2016) Effects of silica and silver nanoparticles on seed germination traits of Thymus kotschyanus in laboratory conditions. J. Rangeland Sci., 6(3): 221-231.

Kharb, R. P. S., Lather, B. P. S. and Deswal, D. P. (1994) Prediction of field emergence through heritability and genetic advance of vigour parameters. Seed Sci Technol, 22: 461-466.

Korndorfer, G., Snyder, G. H., Ulloa, M., Powell, G. and Datnoff, L.E. (2001) Calibration of soil and plant silicon analysis for rice production. Journal of Plant Nutrition, 24(7):1071- 1084.

Liang, Y. C, Sun, W., Zhu, Y. G and Christie, P. (2007) Mechanisms of silicon mediated alleviation of abiotic 
stress in higher plants: A review. Environ Pollut., 147: 422-428.

Liang, Y. C., Wong, J. W. C. and Wei, L. (2005) Siliconmediated enhancement of cadmium tolerance in maize(Zea mays L.) grown in cadmium contaminated soil. Chemosphere, 58: 475-483.

Lin, D. and Xing, B. (2007) Phytotoxicity of nanoparticles: inhibition of seed germination and root growth'. Environ. Pollut. 150:243-250.

Lu, M. M. D, De Silva, D. M. R,, Peralta, E. K., Fajardo, A. N. and Peralta, M. M. (2015) Effects of nanosilica Powder from rice hull ash on seed germination of tomato (Lycopersicon esculentum). Applied Res Develop, 5:1122.

Ma, J. F. and Yamaji, N. (2008) Functions and transport of silicon in plants. Cell Mol Life Sci., 65: 3049-3057.

Ma, J. F., Miyak, Y. and Takahashi, E. (2001) Silicon as a beneficial element for crop plants in Silicon in Agriculture, eds L. E. Datnoff, G. H. Snyder, G. H. Korndoerfer (Amsterdam: Elsevier Science) pag. 17-39.

Ma, J. F. and Takahashi, E. (2002) Soil, Fertilizer and Plant Silicon Research in Japan. Amsterdam: Elsevier Science.

Ma, J. F., and Yamaji, N. (2006) Silicon uptake and accumulation in higher plants. Trends Plant Sci., 11: 392 397.

Ma, J. F., Yamaji, N., Mitani, N., Xu, X., Su, Y. and McGrath, S. P. (2008) Transporters of arsenite in rice and their role in arsenic accumulation in rice grain. Proc. Natl. Acad. Sci. U.S.A. 105: 9931-9935.

Ma, J. F., Yamaji, N. and Mitani-Ueno, N. (2011) Transport of silicon from roots to panicles in plants. Proc. Jpn. Acad. Ser. BPhys. Biol. Sci., 87: 377-385.

Mauromicale, G. and Licandro, P. (2002) Salinity and temperature effects on germination, emergence and seedling growth of globe artichoke. Agronomie, 22:443450.

McNaughton, S.J. (1985) Ecology of a grazing ecosystem: the Serengeti. Ecological Monographs, 55: 259-294.

Mitani, N., Chiba, Y., Yamaji, N. and Ma, J. F. (2009) Identification of maize and barley Lsi2-like silicon efflux transporters reveal a distinct silicon uptake system from that in rice. Plant Cell, 21: 2133-2142.

Naeem, A., Ghafoor, A. and Farooq, M. (2014). Suppression of cadmium concentration in wheat grains by silicon is related to its application rate and cadmium accumulating abilities of cultivars. J. Sci. Food Agric., 95: 2467-2472.
Nair R., Poulose, A.C. and Nagaoka, Y. (2011) Uptake of FITC labeled silica nanoparticles and quantum dots by rice seedlings: effects on seed germination and their potential as biolables for plants. J. Fluoresc, 21:2057-2068.

Ortíz-Castro, R., Valencia-Cantero, E. and López-Bucio, J. (2008) Plant growth promotion by Bacillus megaterium involves cytokinin signalling', Plant Signal Behav., 3: 263-265

Paulkumar, K., Arunachalam, R. and Annadurai, G. (2011) Biomedical applications of organically modified bioconjugated silica nanoparticles. Int. J. Nanotechnol, 8: 653-663

Pavlovic, J., Samardzic, J., Maksimovic, V., Timotijevic, G., Stevic, N. and Laursen, K. H. (2013) Silicon alleviates iron deficiency in cucumber by promoting mobilization of iron in the root apoplast. New Phytol., 198: 1096-1107.

Ranal, M. A. and Santana, D. G. (2006) How and why to measure the germination process? Revista Brasil Bot., 29:1-11.

Sabaghnia, N. and Janmohammadi, M. (2014) Effect of nanosilicon particles application on salinity tolerance in early growth of some lentil genotypes / Wpływ nanocząstek krzemionki na tolerancję zasolenia we wczesnym rozwoju niektórych genotypów soczewicy. Annal UMCS Biol., 69(2): 39-55.

Savant, N. K., Korndorfer, G. H., Datnoff, L. E. and Snyder, G. I. I. (1999) Si licon nutrition and sugarcane production: A review. 1. Plant Nutr., 22: 1853-1903.

Siddiqui, M. H. and Al-Whaibi, M. H. (2014) Role of nano$\mathrm{SiO} 2$ in germination of tomato (Lycopersicum esculentum seeds Mill.). Saudi J. Biol. Sci., 21:13-17.

Supanjani Han, H. S., Jung, J. S. and Lee, K. D. (2006) Rock phosphate-potassium and rock-solubilising bacteria as alternative, sustainable fertilisers. Agron. Sust. Dev., 26: $233-240$.

Suriyaprabha, R., Karunakaran G. and Yuvakkumar, R. (2012) Silica nanoparticles for increased silica availability in maize (Zea mays L.) seeds under hydroponic conditions. Curr Nanosci, 8:1-7.

Takahashi, E., Ma, J. F. and Miyake, Y. (1990) The possibility of silicon as an essential element for higher plants. Comments Agric. Food Chem., 2: 99-122.

Yuvakkumar, R., Elango, V. and Rajendran, V. (2011) Influence of nanosilica powder on the growth of maize crop (Zea Mays L.). Inter Green Nanotechnol, 3:180-190. 


\section{إضافة حبيبات النانوسيليكا لتحفيز إنبات بذور الخيار ونموه (Cucumis sativus)} عبد الله حسن السعيدي'، و محمد محد الجرواني"، و حسن الرمادي"، و طارق الثال"، و عوض عبيد العتيبي؛

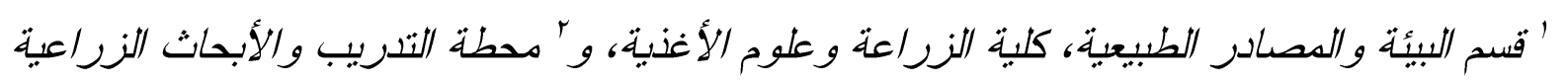

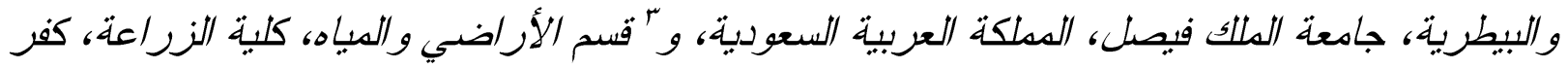

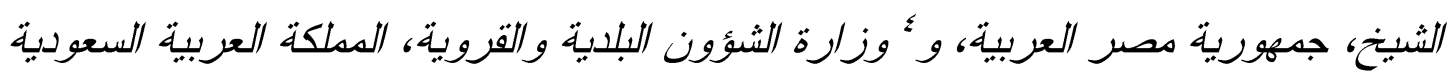
garawany5000@yahoo.com

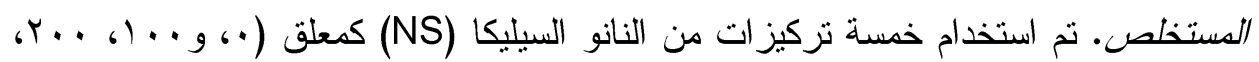

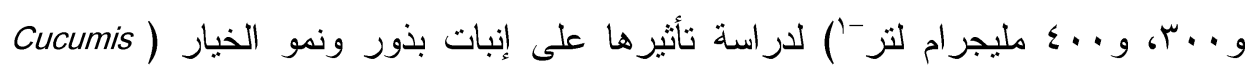
(sativus

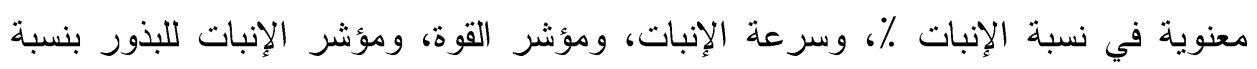
ها

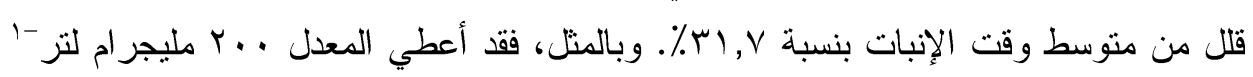
أعلى وزن طازج وجاف من البادرة. ومن جهة أخري، ساعدت جميع معاملات النانوسيليكا على زيادة إنبات ونمو البذور بالمقارنة بمعاملة الثاهد. الكلمات المفتاحية: نانو سيليكا، إنبات البذور، مؤشر القوة، متوسط وقت الإنبات، نمو الخيار. 